and Couze Venn, "Beyond Enlightenment? After the Subject of Foucault, Who Comes?," Theory, Culture E Society, Vol. 14, Nr. 3 (August 1997): 1-28.

3. Herbert Marcuse, "The Realm of Freedom and the Realm of Necessity: A Reconsideration," Praxis 5, 1 (Zagreb: 1969): 24.

4. In CRER 63ff., Marcuse connects his notion of the new sensibility with the analysis of the early Marx on the liberation of the senses; his conception is also influenced by Schiller's conception of aesthetic education.

5. For an argument parallel to mine developed through an engagement with French feminism and poststructuralism, see Kelly Oliver, Subjectivity without Subjects (New Jersey: Rowman and Littlefield, 1998). Oliver provides an ex tended argument that we can talk about subjectivity (and agency) without presupposing or needing a subject, claiming that subjectivity does not necessarily imply a "subject" and that we are better off without such a concept. She develops notions of subjectivity as relational and intersubjective at its "center" and contrasts varying discourses and forms of masculine and feminine subjectivity. This project is parallel, I suggest, to Marcuse and the Frankfurt School, disclosing a surprising affinity between Critical Theory, French feminism, and poststructuralism.

6. Herbert Marcuse, "The Reification of the Proletariat," Canadian Journal of Philosophy and Social Theory, 3, 1 (Winter 1979): 21. See also Marcuse's reflections on Bahro in "Protosocialism and Late Capitalism: Toward a Theoretical Synthesis Based on Bahro's Analysis," in Rudolf Babro: Critical Responses, ed. Ulf Wolter (Whit Plains, N.Y.: M.E. Sharpe, 1980): 24-28.

7. This paper was first presented in a panel at SPEP (Denver, 1998) in which my colleagues David Sherman and Pierre Lamarche presented the contributions of Adorno and Benjamin in rethinking subjectivity. See, in addition, Oliver's account of the contributions to refiguring subjectivity in poststructuralism and feminism, op. cit..

8. See, for example, $R \& R$ 261ff,; "Revolutionary Subject and Self-Government,"; and "Proto-Socialism," 32ff. Yet there are also places in the later Marcuse where he speaks of radical or revolutionary subjectivity, the new sensibility, and new modes of experience, and I am arguing here that while such notions of transfigured subjectivity are still useful, the notion of a "revolutionary subject" should be discarded.

9. See Georg Lukàcs, History and Class Consciousness. Cambridge: MIT, 1971.

\section{Helmut Schelsky's "German" Hobbes Interpretation}

\author{
CARL-GÖRAN HEIDEGREN \\ Lund University
}

Abstract

\begin{abstract}
Helmut Schelsky (1912-1984) is certainly one of the most important and influential German sociologists of the postwar. period. He held professorial chairs in sociology in the Federal Republic for thirty tears (1948-1978): in Hamburg, Münster, Bielefeld and, again, Münster. Owing to the lack of translations Schelsky is, however, not very well known in the English-speaking world. It's also difficult to point out one or two principal writings from bis band; rather we bave to do with a continuous stream of publications on a wide range of topics. In this article, however, I'll focus on Schelsky's controversial postdoctoral thesis on Thomas Hobbes, which he presented on the eve of the Second World War. My discussion is furthermore intended as a contribution to the much wider theme: German intellectuals and National Socialism.
\end{abstract}

\section{I.}

In February 1939 Schelsky defended his postdoctoral thesis in philosophy and sociology on Hobbes at the University of Königsberg. It was planned and prepared to appear as a book in 1942, but due to war circumstances it never did. Not until a few years before his death did Schelsky decide to publish the manuscript in an unchanged form. It appeared in 1981 under the title Thomas Hobbes. Eine politische Lebre. ${ }^{2}$

In a new preface Schelsky quite openly states that at the time of writing and rewriting his thesis (1938-1940) he was in no way an 
opponent of National Socialism. On the contrary his work on Hobbes was in his own view a way of summing up his experiences from the university seminars and political activity as an engaged young Nazi student. At the same time he insists that serious independent scientific work in a liberal spirit was still possible. If we take Schelsky at his word, his thesis on Hobbes is and was intended as both a kind of Nazi philosophy and as a scientific work in a liberal vein.

Schelsky arrived at Leipzig as a young man in 1932 and immediately came under the spell of the "revolution from the right" as advocated by his teachers Hans Freyer (1887-1969) and Arnold Gehlen (1904-1976). ${ }^{3}$ Especially the latter became Schelsky's much admired teacher and friend. Already during his first year in Leipzig Schelsky joined the National Socialist Student Association and, for two years, the Storm troops (S.A.). He took part in the Reichsparteitagen in Nürnberg in 1933, 1934 and 1935, and worked from 1933 for the Amt Rosenberg. In 1934 he published a small work on Sozialistische Lebenshaltung and one year later defended his doctoral thesis on Theorie der Gemeinschaft nach Fichtes Naturrecht von 1796. Another two years later, in May 1937, he joined the National Socialist Party and the following year the National Socialist Teachers Association. Schelsky worked as an assistant for Gehlen first in Leipzig (1934-38) and then in Königsberg (1938-40) and for Freyer in Budapest (1940-41). From the Summer 1941 he took part as soldier and officer in the campaign on the Eastern front. The original preface to Thomas Hobbes. Eine politische Lebre is dated "In the field, 1941."4

The above-mentioned original preface is interesting for several reasons (cf. 13f.). It informs us that the work has its origin in a controversy between the author and Carl Schmitt over "the German Hobbes interpretation in its opposition to the WestEuropean interpretation." What's specific about this "German" Hobbes interpretation, the text also informs us, is that it doesn't reduce scientific theories and doctrines to merely statements about reality, but takes them to be essentially related to and rooted in human action. To show this relatedness and rootedness is furthermore said to be "the task of philosophy in our time," with the reservation that "the methods of this thinking are manifold." Schelsky presents his intention to treat Hobbes as a contemporary, to understand him "philosophically and politically...in the light of the forces of the present," rather than treating him historically as a figure of the past. The actuality of Hobbes is seen in the fact that he was a pronounced opponent to the "System" that erected its dominion in Europe with the Glorious Revolution in 1688. A question of utmost importance then becomes not what is wrong in Hobbes' doctrine, but "what is lacking there." But at the center of the presentation are, according to Schelsky, the "truths" to be found in Hobbes doctrine, and the picture of a political theorist of "European significance."

Paraphrasing Nietzsche it can be said: This is not (only) a preface, this is dynamite! It furthermore poses the question if Schelsky's work can be all the above-mentioned and still be an independent scientific work in a liberal spirit (as the preface from 1981 states).

\section{II.}

Well into the text Schelsky speaks of "two important keys" to the understanding of Hobbes' political philosophy (cf. 279): on the one hand its "anthropological foundation," on the other hand the fact that it addresses the "citizen" and intends to have a certain "effect" on him.' I will proceed backwards and start with the latter key and from there move on to the first.

Hobbes' standpoint, as interpreted by Schelsky, can be summarized in the following way (cf. 321ff.): a doctrine that intends to have a formative influence on men has to orient itself by its recipients and the means to reach and act on them, must 
further take into consideration the situation at the time, and not least who the opponents are and how to counteract their influence. Hobbes' adressee is the citizen (not the ruler as is the case for Machiavelli), his intention is to develop a disposition of loyalty to the state, i.e., to make the citizen freely accept the rule he is subjected to. Hobbes' primary antagonist is the Pope as representing a competing claim to power, his primary means of struggle are to establish a state consciousness founded not on religion but on science. In this sense Hobbes' political philosophy wants to be both a political doctrine and a political deed. ${ }^{8}$ For this reason Hobbes is furthermore said to be the "precursor of a political science that only today is becoming visible in outline" (44).

Carl Schmitt, in his book on Hobbes from 1938, diagnosed a "break" in Hobbes' doctrine. For Schmitt the great Leviathan is a symbol of political unity, of the overcoming of the anarchic state of nature, of the victory over the forces that undermine the power of the State. In exchange for obedience the State offers its citizens protection. However, Hobbes then introduced a distinction between faith and confession, between "inner" and "outer," making faith into an inner, private realm in relation to which the State remains neutral; according to Schmitt he opened up a space for free discourse which soon became the platform for organized societal interests-churches, political parties, trade unions etc.-embarking on a struggle for state power, finally making Leviathan a servant of these "indirect" powers."

Schelsky's rejoinder reads: there is no such break in Hobbes' doctrine (cf. 312f. and 412f.). ${ }^{10}$ Hobbes doesn't leave room for an inner unpolitical space and thereby doesn't open the door for pluralistic powers that finally lead to an end of the unity of the State. His state is not neutral towards what takes place in foro interno of its citizens, rather it ascribes to itself the "right to lead" (427; italics in original) and to give a content to the consciousness of its citizens. What Hobbes, according to Schelsky, has in mind is the opposite of a neutral retreat into an unpolitical inner space, it is rather the politicalization of man's whole existence. The goal of the state is to establish a concrete order in the form of an "order of values" (382)-today, Schelsky adds, we would rather talk about a Weltanschauung-and a corresponding order of life. This concrete order must be anchored among the citizens as habit, conduct and disposition. In this way an identity is established between ruler and ruled, between state and nation. "The democratic consent to dominion, that Hobbes' doctrine of the state contract presents, is at the same time a consent to the domination or leading of consciousness [Bewußtseinsbeherrschung bzw. -führung]!" (427) Democracy for Hobbes means, in Schelsky's interpretation, the recognition of state authority by the people, not the exercise of it. In this way power is transformed into right, and it's no longer adequate to talk of obedience pure and simple on the part of the citizens in relation to the State, but rather of "voluntary obedience" or "allegiance [Treue der Gefolgschaft]" (330). To make the citizens identify with the State is the primary effect that Hobbes' doctrine of politics has in view. For the modern state everything depends, according to Schelsky, on how well it succeeds in this task; it can only develop its power in accordance with-not against-its citizens. Thus we live in a democratic age (with the reservation that democracy is not identical with parliamentary democracy). However in the Western hemisphere it's not the Hobbesian understanding of democracy that has been triumphant, but "the Western states haven't yet come to an end in their discussion of this issue" (423). Writing in the year 1941, it's quite clear that for Schelsky the question of democracy involved far more than a seminar class.

Hobbes is, according to Schelsky, well aware that the formation of a unitary political will in the citizens is a product of political will formation on part of the State, that it amounts to a formation of dispositions from above. The basic fault of Hobbes' political philosophy however is said to be that he thought such a disposition on part of the State could be brought forth by means 
of rational argumentation; "there is no philosophically produced State disposition" (412). On the other hand it's not the free formation of public opinion either that Schelsky has in mind for reaching a political consensus; with Schmitt (and Hobbes) he is acutely aware that societal interests lurks behind every expression of opinion (cf. 425f.). Instead political consensus is rather reached by way of State propaganda, mass psychology, folk education or, in one word, discipline [Zucht]. To bring forth and direct a concrete weltanschauung is for Schelsky not only the most essential right of rulership, but also the most important duty of rulership (cf. 382). What is lacking in Hobbes is furthermore concrete historical goals for the State and thereby also for the citizens that identify themselves with this State (cf. 412). On other occasions Schelsky points out the lack of a philosophy of history in Hobbes (cf. 92) or states that Hobbes limited himself to laying down the presuppositions of the domestic politics for a foreign policy with "national, historical and spatially conditioned [raumbedingten] goals" (329). The concrete goals of the State as a historically situated community is determined by the existing historical situation and by its racial foundation (cf. 31f., 34). The hints that Schelsky gives on the right to assert itself on behalf of the nation and the State, the right to a lebensraum, can hardly be said to be at odds with the actual policy of the German Reich at the time (cf. 387f., 434).

\section{III.}

The foundation of Hobbes' doctrine of the State according to Schelsky is laid by his anthropology. The doctrine of the State is the politicalization of the latter involving the move from descriptive to prescriptive theory.

Schelsky's approach is typological: based on the way they relate to human action he distinguishes between different pictures of man [Menschenbilder]. Every political doctrine rests on and presupposes a certain picture of man, moreover it's true or false only in relation to that picture of man (cf. 19f.). Initially Schelsky distinguishes between two basic pictures of man: the ontological and the dynamic. The first ascribes to man a certain nature independent of his action, the latter sees in man's conscious action his very essence, i.e., man is what he makes of himself. In a second round Schelsky distinguishes between optimistic and pessimistic pictures of man (ontological), and between intellectualistic and activistic pictures of man (dynamic). I will here concentrate on the latter distinction. The basic option in this case is: either the universal and eternal (reason, God etc.) stands in the foreground as the goal of human activity or the emphasis is upon a given concrete situation and a given concrete past as points of departure for human, future oriented, action. ${ }^{11}$ Whereas the former assigns to man the task or mission to realize the State of reason or God's empire on earth, the latter knows of nothing eternal in man, no predetermined goal of human activity, but only of the concrete acts by which man secures his own existence and propels himself into the future. Hobbes, according to Schelsky, represents neither a pessimistic nor an intellectualistic picture of man, but an activistic one. For the activist man's self-preservation is an unsolved problem and a task that demands from man an orientation towards the future for the sake of securing not only his bare survival but also a human way of life in a community. Furthermore: "For him [the activist] thought has in no way a precedence over action, but is rather a function of bis active life. Different theories of thought are possible here which however all agree that thought in relation to acting plays the role of serving, advising, assisting, directing, in short, that it's there for the sake of action." (36; cp. 44ff.)

Now according to Schelsky the doctrine that every political doctrine presupposes one of the pictures of man mentioned above is itself a political doctrine, insofar as it rests on a particular picture of man, namely, an activistic one. Those who argue that political doctrines, whose object are in a broad sense human action in state and society, are rooted in different pictures of man, 
above all in the way they conceive of human action, have in fact already opted for an activistic picture of man. It's accordingly in the light of an activistic picture of man that anthropology becomes of central importance for the understanding of political doctrines.

At a certain risk of getting lost in Schelsky's detailed and nuanced interpretation of Hobbes' anthropology, I want to briefly bring out three central components (cf. Part Two): a) The importance of language as the dividing line between man and animal. With human language man is for Hobbes given the ability to count (i.e., to abstraction), the ability to teach and to communicate with others, and the ability to give and take orders as well as to make promises. b) Closely related to the use of language is action according to plan. Man has the capability to overview the intention and goal of action, i.e., to act according to a preconceived plan. The basic form for such action according to plan is the technique. Language at the same time makes possible and is at the disposal of man's interaction with his environment. This interrelatedness of language and deed is "the keystone of Hobbes' doctrine of man" (59). c) Furthermore, man is power as a being able to. Given his lack of a once and for all fixed nature, man has to secure his own existence through action, through his own power by finding out or knowing how and his capability to carry through his plans. In continuation with this anthropological concept of power is the political as the ability to carry through action oriented towards the future according to plan against other plans of action oriented towards the future.

The above-mentioned concepts form the basis of an anthropology that in all aspects centres around buman action as the execution of a preconceived plan: thought is primarily related to action, volition is the action itself as related back upon a previous deliberation, and free is that action which proceeds unimpeded according to plan. All human capabilities and powers are involved and interact with one another by the fulfillment of a premeditated action. Methodologically this means the rejection of any attempt to understand or 'deduce' human nature from some inherited character or a particular ability taken in isolation.

If one author were singled out to whom there is almost exclusively positive references in Schelsky's work on Hobbes that would probably be John Dewey. ${ }^{12}$ To give just two examples: in relation to Dewey's doctrine of deliberation and choice of action, Schelsky talks about "an astonishing parallel to Hobbes" (167), and, more generally, he finds "a large degree of correspondence in the substantial statements and the definition of concepts" (142) between Hobbes and Dewey in their respective anthropologies (see also $35 \mathrm{f}$., $38,158 \mathrm{f}$., 161ff., 168, 182f., 189f., 429). These positive references are not surprising in so far as the American pragmatist also is said to represent an activistic picture of man. They are however surprising in so far as Schelsky at the time understood himself as a National Socialist and Dewey's name is closely associated with American democracy. ${ }^{13}$ In what follows I want to complicate matters further by drawing a line to the praxeology of Pierre Bourdieu.

In an interview some years ago Bourdieu answered the question if there isn't a parallel between his theory of habitus and especially Dewey's pragmatism:

Indeed, the affinities and convergences are quite striking, and I believe I understand what their basis is: my effort to react against a deep-seated intellectualism characteristic of all European philosophies (with the rare exceptions of Wittgenstein, Heidegger and $\cdot$ Merleau-Ponty) determined me, unwittingly, to move very close to philosophical currents that the European tradition of "depth" and obscurity is inclined to treat as foils, negative reference points. ${ }^{14}$

No doubt Bourdieu could also have mentioned Schelsky (and Gehlen-and perhaps even Hobbes) as "rare exceptions" to the dominant European tradition. Therefore it's hardly surprising 
that the notion of babitus is to be found in Schelsky too (cf. 181, 186f., 190f., 195, 271, 275ff., 278, 282f.). It makes its appearance in connection with his discussion of man's bearing (in German Haltung as the translation of Hobbes's latin word ingenium). A specific habitus or bearing becomes visible in the long run; it doesn't predetermine any particular action, but as something incorporated, an acquired immediacy, a disposition to act in certain ways, it puts its mark on the sequence of actions that makes up a human life. The bearing doesn't act mechanically, but rather through the intellect; as a predetermining power it "plays a role in the deliberation, constitute its rules and standards, by which it measures things and inwardly puts them to test" (185)..$^{15}$ Perhaps one could speak of a conditioned freedom, in so far as our habitus both limits the field of possible actions and makes possible certain ways of action. "The past life of man is a predetermining and limiting power, but also present in every action as an effortless ability at one's disposal." (184) A connection between the notion of habitus and the previously mentioned formation of a State consciousness is established in the following way:

Because the habitus of all actions constitute ethical life [Sittlichkeit], and the former is produced through habit, education and continual influence from authority, the State or ruling power in truth produces the disposition of men or can at least produce and in a sense exhort it, because the production in the widest sense of the word is alone or can at least be in the hand of the State. (278-9)

In my view it's justified to talk of a rather surprising family resemblance between Schelsky's "German" Hobbes interpretation, Dewey's pragmatism and Bourdieu's praxeology as far as basic anthropological assumptions are concerned. At the same time they differ radically in their respective political or ideological tendencies: National Socialism, American democracy and French Leftism. This is a puzzling finding. From more or less common ground the three authors diverge in very different directions. What does this imply concerning the relation between anthropology and politics?

Schelsky, in his own self-understanding, when he wrote his thesis on Hobbes was a National Socialist-although, as he writes in the preface from 1981, with "a very subjective interpretation of its contents" (9). In Hobbes' philosophy he saw on the one hand a descriptive anthropology and on the other hand a prescriptive doctrine of the State. The latter is further said to be the politicalization of the former. ${ }^{16}$ To put the questions rather clumsy: Is Schelsky's Hobbes interpretation an example of Nazi philosophy or ideology from beginning to end? Because of the family resemblance between Schelsky, Dewey and Bourdieu in matters of anthropology the answer, I think, must be negative. ${ }^{17}$ For the very same reason there can be no necessary connection between for example an activistic picture of man and Nazi philosophy or ideology. Does a certain anthropology allow for very different forms of politicalization? This is most probably the case. How is it possible that a certain type of anthropology allows for such very different politicalizations as our example shows? Doesn't the anthropological foundation in any way limit the kind of political philosophy or ideology that comes out in the end? It would be rather strange if that wasn't the case. The question now becomes: At what point and by which argumentative moves does Schelsky make a turn in the direction of Nazi philosophy or ideology? I will return to these questions in a while, after having made a comparison on certain issues with Arnold Gehlen, Schelsky's teacher and long time friend.

\section{IV.}

The "German" interpretation of political doctrines, according to Schelsky in the original preface to his thesis on Hobbes, understand these as essentially related to and rooted in human action. The "methods" of this thinking are however said to be "manifold." A year before Schelsky wrote his preface Gehlen 
published a large-scale study in philosophical anthropology that was soon to become famous: Der Mensch. Seine Natur und seine Stellung in der Welt (1940). The concept of human action is certainly at the forefront of Gehlen's interpretation of man, but his basic approach differs radically from Schelsky's. Instead of a typology of pictures of man we find an empirical philosopby that, building on the findings of the empirical sciences, puts forward hypotheses on man's nature and place in the world. The picture of man that such an empirical philosophy develops is antimetaphysical in the sense of being essentially provisional, fallible and open for revision.

There is reason to believe that Gehlen relatively early felt the attraction of National Socialism. A letter from August 1931 shows him involved in the project of writing a kind of handbook presenting "the philosophy of National Socialism." There exists fragments of a manuscript from the years 1933/34 showing Gehlen still at work on that project. A central idea that he intended to develop seems to have been that "behind the theories of race...is to be found the myth of race," because the core and substance of every weltanschauung that "grips hold of the whole of man" (GA 3, 792) is the myth. ${ }^{18}$ It's not a farfetched conclusion to assume the influence of Sorel behind this theory of the myth of race as a mobilizing force in men's life.

Gehlen's pro-Nazi attitude seems to have culminated in 1935, slowly giving way to a more distanced and ambivalent attitude. ${ }^{19}$ Be that as it may, Gehlen on all circumstances made a brilliant career during the Nazi regime, although not quite free from problems and set backs. He joined the National Socialist Party in May 1933, the National Socialist Teachers Association in August the same year. At the age of thirty he became professor of philosophy in Leipzig, four years later, 1938, his professorship was transferred to Königsberg, and another two years later he took up a position in Vienna. In 1942 he became chairman of the German Philosophical Association. But there was resistance from the Nazi-authorities to his appointment as professor in Leipzig, and he was severely criticized by the Nazi-philosopher Ernst Krieck in 1935 and 1940, and the handbook for studies in philosophy that he wrote in 1944 wasn't allowed to be published. ${ }^{20}$

If we turn to Gehlen's principal work in philosophical anthropology from 1940 we find, just as we found in Schelsky's work on Hobbes, a great number of references to Dewey and American pragmatism. In comparison to Schelsky these references are however more ambivalent: on the one hand very positive, on the other hand polemical. "The view of pragmatism is to prefer to all others because it is so far the only philosophy that of principle looks upon man as an acting being." (GA 3, 347) Gehlen doesn't hesitate to acknowledge the great merits of a philosophical approach that closely relates consciousness and knowing to human action and making. At the same time there is a general tendency to claim that a pragmatist line of thought is to be found already by the main figures of German Idealism and by Schopenhauer (cf. GA 3, 346, 580, 635, 640f.). ${ }^{21}$ Furthermore Gehlen becomes very critical of American pragmatism at the moment it "wants to be more than just a pragmatic theory of knowledge, namely polemical enlightenment" (GA 3, 656; for the following see 356f. and 655-9). He finds in James and Dewey an "enlightenment optimism," a too strong belief that "rational science or philosophy" can give orientation in life and bring forth a "rational social order." Instead of embracing a "pragmatic rationalism" succumbing to the illusion of a self-sufficient operational thinking, Gehlen makes himself the spokesman of a "counter-enlightenment from the spirit of science" insisting that human experience and the necessity to act goes further than science and the possibility of knowing, and that therefore science too is in need of "guidance [Führung]" that takes its point of departure exactly from that "broad experience" which goes beyond the scope of science. The corrective of an "intellectualism" that loses contact with basic human needs and 
necessities lies in the "necessity of guidance: education, discipline, self-discipline, leadership and rulership."

Here we arrive at the "supreme systems of guidance [oberste Führungssysteme]," as the title of the last chapter in the book from 1940 reads, and thereby is meant religions and weltanschauungen (see GA 3, 709-743). ${ }^{22}$ Those systems relates to the whole of man and secures the satisfaction of certain elementary and eternal needs and interests, such as man's need for an interpretation of the world and himself, man's need for guidance of action [Handlungsführung] and formation of character [Charakterformierung], and, finally, man's need for means to cope with his constitutional vulnerability and powerlessness. In more ancient times a religion was at the same time a weltanschauung, whereas in modern times science has tended to monopolize the interpretative task and leaves to religion, in a more or less individualized form, the third task: to take care of man's soul. The second task is today fulfilled by nonreligious weltanschauungen: by way of natural ethics and politics they give guidance to action and form character. Moreover according to Gehlen it's "in Germany proved as a matter of fact that an immanent disciplinary ideal order [Zuchtbild] is capable of establishing and carrying through basic principles of action, to establish a stable organization for the growth and achievements of the people, as well as point to and realize necessary, common tasks" (GA 3, 739). This is the primary task for a National Socialist weltanschauung and for the National Socialist state. ${ }^{23}$

Given Gehlen's insistence on a weltanschauung that forms the character and gives guidance to action, the question of the capacity and goals of education must be of utmost importance. In an article from 1941 entitled Anlage, Vererbung und Erziebung, Gehlen comes to speak of what "the German idea of education" (GA 3, 864) involves. Just as the content of every other education is dictated by the historical situation of the national community, i.e., politically motivated, so is the German. The German idea of education according to Gehlen has for its overarching goals on the one hand the development of expertise in a particular field [Fachmenschentum] and on the other hand the preservation of the national community. The concrete content is provided through the national weltanschauung, and as destined to lead the whole people this "must therefore be simple, must in a few words point out the task, the opponent, and the duties" (865). The conclusion seems to be that education in Germany has to be not only subordinated but also instrumental to the historical situation and the concrete order of the State, and that the idea of its tasks is articulated through the weltanschauung of the State. "The national community demands not simply the selfabandonment of the individual, but active, permanent, judicious and disciplined self-abandonment." (865)

\section{V.}

Although Schelsky's and Gehlen's basic approaches differs radically-typology of pictures of man vs. empirical philosophy-they are both representatives of an anti-intellectualistic orientation in theory, arguing for the primacy of buman action, that abstract thought is there for the sake of action and not the other way around. This brings them close to pragmatist and praxeological approaches. They also both insist on the necessity of the formation of human character by way of education, discipline, self-discipline, leadership and rulership. They further both insist on the need for a weltanschaunng on behalf of the State that furnishes the supreme guidance of the citizens. The formation of a State disposition is perhaps the central task of the State, thereby securing itself a democratic legitimacy (although not in the sense of Western democracy). Such a legitimacy is secured if the State succeeds in laying down goals which the citizens are willing to acknowledge and identify with. Schelsky and Gehlen becomes the spokesmen of a counter-enlightenment through insisting that there is no scientifically produced State disposition, and that science too is in need of guidance. The 
weltanschauung of the State takes into account the broader experience of the national community and sets up the goals and determines the tasks of the State on the basis of the given concrete historical situation. The need of the State and the national community to secure their existence and a certain way of life for its citizens has an absolute priority. Everything else would be a relapse into intellectualism. "In the presupposition," Schelsky writes when he for once criticizes Dewey, "that the State is to be formed according to the knowledge of its true essence... Western democracy is platonic" (441). Thus from different starting points and following different paths Schelsky and Gehlen end up in positions that closely resemble each other and could be said to make one bid on what constitutes a National Socialist weltanschauung. ${ }^{24}$

\section{VI.}

In conclusion: To argue that Schelsky's “German" Hobbes interpretation has nothing to do with the author's National Socialist engagement seems to be simply wrong. To argue that it is through and through National Socialist philosophy or ideology also seems to be simply wrong. If the latter were the case I don't know how to account for the parallels to Dewey and Bourdieu as concerns basic anthropological assumptions. Generally, I think the qualification of theories as 'in their very essence' or 'through and through' of such and such a character more often shows an ideological concern than an analytical interest. So obviously the truth is to be found somewhere between the two extremes. This raises a general metbodological issue that goes far beyond Schelsky's interpretation of Hobbes: How to proceed in the analysis of works that seems to have both a philosophical substance and a strong ideological bent? To sort out the findings into two neat boxes is probably an impossible undertaking. Most likely every basic theoretical approach has a certain flexibility and can be developed in different directions (just as a common position can be reached by different paths).
Along the way options are made that adds up to very different outcomes as concerns ideological tendencies. On the other hand the options are most probably made in the light of ideological convictions or commitments that were there from the beginning, which brings a certain circularity into the theoretical construct. The flexibility of theoretical approaches however is hardly unlimited. Given certain basic theoretical options not any ideological outcome is possible without violent argumentative moves.

Schelsky's "German" Hobbes interpretation must in my view be read as an effort to take the philosophical meaning of National Socialism seriously. It's a work on a political theorist of the past, but it's just as much a work about the present. For Schelsky there is a philosophical path to National Socialism, not a compelling one, but certainly one that doesn't lack coherence and consequence in its argumentation. It starts out from an antiintellectualism and an activistic picture of man, and it ends in an activistic state doctrine and an insistence on the formation of a State disposition by way of discipline.

\section{Notes}

'For a short overview of Schelsky's life and work see my article "Transcendental Theory of Society, Anthropology and the Sociology of Law: Helmut Schelsky - An Almost Forgotten Sociologist," Acta Sociologica 40 (1997), 279-290.

${ }^{2}$ Helmut Schelsky, Thomas Hobbes. Eine politische Lebre, Berlin: Duncker \& Humblot, 1981. If not otherwise stated all references in the following are to this work.

${ }^{3}$ Hans Freyer was professor first in sociology (1925-1933) and then in political sciences (1933-1938). In 1931 he published the book Revolution von rechts. Gehlen is presented later in the text.

${ }^{4}$ The information is put together from George Leaman, Heidegger im Kontext. Gesamtüberblick zum NS-Engagement der Universitätsphilosophen, Hamburg \& Berlin: Argument-Verlag, 1993, 74f. and Bernhard Schäfers, "Person und Institution. In Memoriam Helmut Schelskys (14. Oktober 1912 24. Februar 1984)," Kölner Zeitschrift für Soziologie und Sozialpsychologie 36 (1984), 420f. Schelsky writes himself about the intellectual situation at the University of Leipzig, including his own development, in "Zur 
Entstehungsgeschichte der bundesdeutschen Soziologie. Ein Brief an Rainer Lepsius," Kölner Zeitschrift für Soziologie und Sozialpsychologie 32 (1980), $420 \mathrm{ff}$.

${ }^{5}$ Cf. Carl Schmitt, "Der Staat als Mechanismus bei Hobbes und Descartes," Archiv für Rechts-und Sozialphilosophie 30 (1936/37), 622-632, Helmut Schelsky, "Die Totalität des Staates bei Hobbes," Archiv für Rechts- und Sozialphilosophie 31 (1937/38), 176-193, and Carl Schmitt, Der Leviathan in der Staatslebre des Thomas Hobbes. Sinn und Feblschlag eines politischen Symbols (1938).

${ }^{6}$ This is a reference to Gehlen's empirically oriented philosophical anthropology which after the war also became Schelsky's intellectual point of departure (cf. 11).

'Looking back at his Hobbes interpretation forty years later, Schelsky emphasizes the same two aspects as of importance also for contemporary Hobbes scholarship (cf. 8).

${ }^{8} \mathrm{Here}$ Schelsky, inspired by Hans Freyer's studies on Machiavelli (cf. 8), in my view comes very close to the kind of approach in the history of political ideas that today is strongly associated with Quentin Skinner.

${ }^{9} \mathrm{Cf}$. Carl Schmitt, Der Leviatban in der Staatslebre des Thomas Hobbes. Sinn und Feblschlag eines politischen Symbols, Stuttgart: Klett-Cotta, 1982, ch. 5-6.

${ }^{10}$ The question of which interpretation fits the facts, i.e., what is the better Hobbes interpretation, must here be left out. According to Günter Maschke Schelsky's book rather answers the question "How would Hobbes have conceived the realization of his goals under the conditions of the 20th century?" See his epilogue "Zum 'Leviathan' von Carl Schmitt” in Carl Schmitt, Der Leviathan in der Staatslehre des Thomas Hobbes, 195.

11"Race, national traditions, historical situation, family, profession, landscape, education, area of responsibility" are for the activist "the basis of his picture of man" (34).

${ }^{12}$ Schelsky's primary reference is to the German translation of Human Nature and Conduct (1922). In the introduction to his collection of essays Auf der Suche nach Wirklichkeit. (Düsseldorf-Köln: Eugen Diederichs Verlag, 1965) Schelsky writes that, coming from an occupation with James and Dewey, he tried to interpret Hobbes as "the first consistent pragmatist thinker" (7). One also finds in Schelsky an abundance of positive references to Gehlen and Schmitt, although in the latter case often paired with polemics. Very ambivalent is the reception of the writings of Leo Strauß (cf. 217f., 263, 280f., 316).

${ }^{13}$ On one occasion Schelsky talks about Dewey as an "uncurable democrat" (441) in the sense of that Western democracy he himself strongly repudiates. On the reception of American pragmatism in Germany see Hans Joas, "Amerikanischer Pragmatismus und deutsches Denken. Zur Geschichte eines Mißverständnisses," Pragmatismus und Gesellschaftstheorie, Frankfurt am Main: Suhrkamp Verlag, 1992, 114-145. Joas, with a certain astonishment, establishes the very positive and insightful reception of James and Dewey in the 1930s among a group of intellectuals with sympathies for National Socialism, and especially points to Eduard Baumgarten, who had spent six years in America in the 1920s and in the following decade wrote on pragmatism on a high level (see 42 esp. Die geistigen Grundlagen des amerikanischen Gemeinwesens. Bd. 2. Der Pragmatismus. R. W. Emerson, W. James, J. Dewey (1938). For Baumgarten, as for Schelsky and Gehlen, pragmatism according to Joas "served the purpose of an activistic ideology" (129). Schelsky quotes Baumgarten once with approval (cf. 422).

${ }^{14}$ Pierre Bourdieu \& Loïc J. D. Wacquant, An Invitation to Reflexive Sociology, Oxford: Polity Press, 1992, 122. No doubt there is an anthropology underlying Bourdieu's sociology. This has been spelled out in a well-informed Swedish dissertation on Bourdieu in the following way: "man (or rather the male) is an exchanging and struggling being, inclined to strive for the recognition of other men (in the first place from other males) and to dominate them" (Donald Broady, Sociologi och epistemologi. Om Pierre Bourdieus författarskap och den bistoriska epistemologin [Sociology and Epistemology. On Pierre Bourdieu's Authorship and the Historical Epistemology], Stockholm: HLS Förlag, 1990, 434).

${ }^{15}$ Central to Dewey is the notion of habit, which however is to be understood not in terms of mechanical repetition, but as "an active and creative relation to the world" (Bourdieu \& Wacquant, An Invitation to Reflexive Sociology, 122). Cp. Dewey: "Repetition is in no sense the essence of habit. Tendency to repeat acts is an incident of many habits but not all. (...) The essence of habit is an acquired predisposition to ways or modes of response, not to particular acts except as, under special conditions, these express a way of behaving. Habit means special sensitiveness or accessibility to certain classes of stimuli, standing predilections and aversions, rather than bare recurrence of specific acts. It means will." (Human Nature and Conduct, Carbondale and Edwardsville: Southern Illinois UP, 1988, 32).

${ }^{16}$ For example the "war of all against all," as part of Hobbes' famous doctrine of the state of nature, is interpreted by Schelsky as a politicalization of Hobbesian anthropology in that it's a "mythical catchword for a general social catastrophe" (342) that calls upon men to avoid it through action according to plan.

${ }^{17} \mathrm{~A}$ family resemblance of course doesn't exclude differences. Maybe it is the case that already on the level of the concept of action important differences are to be found among the three authors. The question then is, how far these differences account for the radical differences in political orientation.

${ }^{18}$ If not otherwise stated I quote from Arnold Geblen. Gesamtausgabe, Frankfurt am Main: Vittorio Klostermann, Bd. 2. Philosophische Schriften II (1933-1938), hrsgg. v. Lothar Samson, 1980 [= GA 2], Bd. 3. Der Mensch. Seine Natur und seine Stellung in der Welt. Textkritische Edition unter Einbeziehung des gesamten Textes der 1 . Auflage von 1940, hrsgg. v. Karl-Siegbert Rehberg, 1993 [ = GA 3].

${ }^{19}$ In an article from 1935 - Der Idealismus und die Gegenwart - Gehlen even quotes Hitler with approval (cf. GA 2, 357)! In the same article he talks about 
"the National Socialist weltanschauung" as well as "the National Socialist philosophy and theory of science" (354).

${ }^{20}$ See Lothar Samson, "Nachwort," GA 2, 414ff.; Karl-Siegbert Rehberg, "Nachwort des Herausgebers," GA 3, 753f.; George Leaman, Heidegger im Kontext, 41; Gerwin Klinger, 'Freiheit als 'freiwillige Aufgabe der Freiheit.' Arnold Gehlens Umbau des Deutschen Idealismus," Deutsche Philosophen 1933, hrsgg. v. Wolfgang Fritz Haug, Hamburg: Argument-Verlag, 188ff.

${ }^{21}$ At one place Kant is for example frankly called a "prepragmatist" (GA 3, 639). For a connection of Hobbes to James and Dewey, with a reference to Baumgarten, see GA 3, 579f.

${ }^{22}$ Gehlen in this chapter several times points to the close relation between his notion of "supreme systems of guidance" and Alfred Rosenberg's notion of "disciplinary ideal orders [Zuchtbilder]" (cf. GA 3, 710, 733, 742).

${ }^{23}$ In the article Der Idealismus und die Gegenwart from 1935 Gehlen states that "the National Socialist weltanschauung is total, i.e., lays claim to penetrate every area of life and to bring it in correspondence with its fundamental views" (GA 2, 354). In comparison the task of a weltanschauung in Der Mensch seems to be more restricted; it shall not interfere in the tasks of science and (in a restricted sense) religion. How this restriction is compatible with the claim that science too is in need of guidance isn't quite clear to me.

${ }^{24}$ It should be noted that this is a weltanschauung in which an antisemitism, as far as I can see, plays no essential role. Gehlen's philosophical anthropology is on the contrary said to be a "science of utmost importance, just because it's situated before every science of race" (GA 3, 487).

\section{AUthoritarianism IN}

THE NeTHERLANDS: Mission COMPLETED?

\section{DOWNWARd TRENDS IN AUTHORTTARIANISM IN THE NeTHERLANDS 1970-1992 WITH AN INTERNATIONAL COMPARISON OF WORLD DATA}

\author{
Jos D. Meloen
}

University of Leiden, The Netherlands

\section{Abstract}

Three basic bypotheses on authoritarianism in The Netherlands are proposed. A composite Middendorp data set was used, that included five national random samples in The Netherlands: 1970, 1975, 1980, 1985 and 1992. The first bypothesis maintains that the authoritarianism syndrome will not disintegrate in time. This stability-bypothesis was strongly supported in the 1970-1992 period. The second bypothesis suggested that the lev els of authoritarianism bave steadily decreased in time. This decreasing-levels bypothesis also received consistent support. Non authoritarian attitudes are now supported among a majority of the population. It is argued that the decrease of authoritarianism levels cannot be attributed to disintegration of the authoritarianism syndrome proper. Hypothesis three stated that The Netherlands is among the lowest in levels of authoritarianism and state authoritarianism in the world. This lowest level-bypothesis was explored using cross national data of authoritarian attitudes and state authoritarianism. The in dicators indeed suggest that The Netherlands rank among the lowest in authoritarian attitudes as well as in state authoritarianism, together with Scandinavia, Iceland, Canada and New Zealand. The results suggest that the quest of Adormo et al. may have been completed, at least for countries like The Netherlands in the 1990s. 